\title{
Strategies for Working with Soviet Past in the Post-Soviet Cultural Space (The Cases of TV-series Thaw, Kolyma Tales Performance by Yeltsin Centre's 'V tsentre' theatre studio and Yury Dud's YouTube fillm Kolyma - Birthplace of Russia's Fear)
}

\section{Lilia Nemchenko}

Ural Federal University named after the first President of Russia B.N.Yeltsin, Yekaterinburg, Russia

\section{Abstract}

This article explores some of the strategies used to reconstruct the Soviet past in contemporary Russian culture. Soviet past is ubiquitous in contemporary Russia. Over the past decades, it has become simultaneously an object of nostalgia, an object of mythologisation, and an object of myth deconstruction. This article analyses

Corresponding Author: Lilia Nemchenko lilit99@list.ru

Received: Month 2020 Accepted: Month 2020 Published: 28 September 2020

Publishing services provided by Knowledge E

(c) Lilia Nemchenko. This article is distributed under the terms of the Creative Commons

Attribution License, which permits unrestricted use and redistribution provided that the original author and source are credited.

Selection and Peer-review under the responsibility of the Convention-2019 Conference Committee. the concepts of nostalgia, mythologisation and demythologisation and explores the strategies for aesthetisation, glamorisation, critique and deconstruction of the past. The research presented here is based on the analysis of creative texts produced in different art forms: cinema and drama, as well as various communication media that cater to different audiences - traditional one (film screenings, TV broadcast, stage plays) and new/younger one (video bloggers on YouTube). This article suggests that the strategies employed by various authors who work with the Soviet past depend not only on their value attitudes but also on their chosen communicative channels. Thus, the 'traditional' audience of mass TV channels is exposed to openly nostalgic interpretations of Soviet past, while the 'younger' audience of experimental theatre studios and YouTube channels, which lacks direct experience of Soviet period, requires different approaches. However, in all these art forms it is possible to move beyond nostalgia producing works that challenge retro-expectations.

Keywords: nostalgia, mythologisation, deconstruction, The Thaw TV series, Kolyma Tales performance, Yury Dud

\section{Introduction}

The Soviet past is present in contemporary Russian culture on several levels. First, there is a well-developed fashion for all things Soviet: restaurants titled 'USSR' or 'Kitchen Factory', Soviet symbols used by fashion designers etc. Second, the TV series immersing viewers in the Soviet past inevitably attract high ratings. Over the past decade alone 
an incomplete list of such series include: 2008 Galina by Vitaly Pavlov - about the daughter of Leonid Brezhnev; 2011 The Case of Grocery No.1 (Delo gastronoma No.1) by Sergei Ashkenazy starring Sergei Makovetsky - about the director of Yeliseyevsky store on Gorky street in the early 1980s; 2011 Furtseva by Sergei Popov starring Irina Rozanova - about the Soviet Minister of Culture in the 1960s; 2012 Once Upon a Time in Rostov (Odnazhdy $v$ Rostove) by Konstantin Khudyakov - about the tragic Novocherkassk events of 1962; 2013 Lyudmila by Aleksandr Pavlovsky - about the singer Lyudmila Zykina; 2013 The Thaw by Valery Todorovsky - about the cinema and its makers during the Khrushchev's 'thaw'; 2015 Aleksandrov and Orlova by Vitaly Moskalenko - about the famous 1930s-1940s film director and his wife who starred in his movies, etc.

In these artistic texts the past becomes a source of nostalgic feelings. Two and a half decades of post-Soviet culture provide ample material for the analysis of various strategies employed in working with the concept of nostalgia.

The modern concept of nostalgia is used in two meanings: first, as a personal loss of connection with the past and the desire to return to its idealised version; second, as an ideology (as exemplified by contemporary Russian ideological rhetoric with its calls to the return of conservative values).

Since only a minority of citizens experienced post-USSR euphoria yet almost everybody had to deal with the devastating economic consequences, nostalgia as a personal emotion has become an object of ideological manipulation. Nostalgia and the accompanying set of emotions began to be constructed through media, art projects, entertainment industry, event management etc. This construction was both possible and successful because the Soviet experience was common for the vast majority of the population.

The uniqueness of Russian cultural experience lies in the fact that the official Soviet culture lacked 'nostalgia' as a feeling of the lost past -- it may be described as a neophyte practice that created a mobilising project of 'living without nostalgia'. The post-Soviet experience, on the other hand, is an experience of living with nostalgia. In their article The Dimensions of Nostalgia M. Chase and C. Shaw outlined several conditions required for the nostalgia to emerge:

1. The feeling that the present is in some ways defective, which reflects the disaffection of various population groups and engenders nostalgic gaze into the past;

2. The presence of material things (objects, architecture, images, films) that fulfil the expectations of the nostalgic subjects. Modern societies, with their ideology of constant change and innovation, and subsequent erosion of traditional value systems, provide 
fertile ground for the emergence of nostalgic moods. Nostalgic moods are therapeutic, they relieve stress, both generational and personal. [1]

Russian cinematic tradition of the late twentieth and early twenty-first centuries quickly succumbed to the nostalgic moods, exploring the state of frustration created by the tectonic historical shifts and the painful break with the Soviet past through the demythologisation of this past (for Soviet people history was usually a mythology, not a historical knowledge), revealing repressive practices and exposing testimonies that were traumatic for the ordinary audience. While such films as Pavel Chukhray's A Driver for Vera (Voditel' dlya Very), Dmitry Meskhiev's Our Own (Svoyi) and Nikolay Dostal's Lenin's Testament (Zaveshchaniye Lenina) were hugely popular among the viewers, Aleksei Uchitel's epic The Edge (Kray) went almost unnoticed, and the TV broadcast of war veteran Pyotr Todorovsky's Riorita produced a wave of outrage together with the accusations of Russia-bashing. Both The Edge and Riorita were created during the period of transition from the aesthetical to the ideological nostalgia. Media-constructed nostalgia for the Soviet past forms a part of the conservative project offered by today's Russian government.

The first stage in the construction of Soviet nostalgia was an aesthetic one. Four years after the USSR ceased to exist, at the New Year's Eve of 1995-1996, the main state TV channel launched a project titled Old Songs about the Main Things (Starye pesni o glavnom). It became one of the most successful projects by Konstantin Ernst and Leonid Parfyonov. The show's success was based on the selection of quality songs and good performers. Favourite old tunes and familiar lyrics, packaged in a new interpretation, provided a sense of continuity, recreated the lost experience of community. Nostalgic emotions were ambivalent - the joy of recognition and the pride in the beautiful melodies and lyrics were accompanied by the bitter sense of loss.

The next stage in the construction of Soviet nostalgia centred around the practice of glamorisation, which transformed Soviet symbols into empty beautiful forms. Such Soviet markers (labels, emblems of pioneer childhood, food products) were strategically utilized by the designers of the Gum project

Construction of nostalgia proceeded not only through aesthetisation and commercialisation, but also through mythologisation of the past. Ideal conditions for the emergence of nostalgic moods exist when people feel disaffected by the present (either in social or personal dimension), as well as when there is a personal experience of the past. From the mid-1990s, we have been witnessing a shift in the temporal object of nostalgia: from the 1960s and the interest in the 'thaw' period to the mythologisation of the 1970s. The myth of the 'thaw' already emerged in late Soviet years. It was based on the 
objective facts: the 1960s antitotalitarian drive, its anti-Stalinism (Khrushchev's speech at the 20th Communist Party Congress), Soviet triumphs in science, technology and art (Yury Gagarin, Sovremennik Theatre, Taganka theatre, 'poetic cinema', A.I.Solzhenitsyn, etc.).

Unlike the nostalgia for 1960 s, nostalgia for 1970 s, the so-called period of stagnation (zastoy), is based on foundations that are patently untrue. For example, typical features of the economy of the 'well-developed socialism' - such as stagnation, shortages, inauthentic personal relationships (see, for example, the 1974 short film Stop the Potapov (Ostanovite Potapova) by Vadim Abdrashitov, whose main character lies to everybody) - become mythologised as positive characteristics of the era: stability, prosperity and social security. It is worth noting that "despite relative prosperity, in the 1970s neither stability, nor Soviet social security, nor equality, nor the humanity in interpersonal communications were experienced as something positive. They either went unnoticed, were ridiculed as illusory, or were interpreted as something negative" [2]

Mythologisation and demythologisation of the Soviet past are the processes that happen simultaneously. An important demythologising tool is an exposure of socialism's repressive tactics and demonstration of facts traumatic for the general population.

Creative practices employed in the overcoming of nostalgia for the Soviet past do not deny importance of nostalgic experience as a personal emotion - yet they utilise various tools (demythologisation, reconstruction and deconstruction of the past, or even its absurdisation) to warn about danger and trauma lurking within the collective construction of nostalgic moods. By doing this, they perform a heuristic function, which is traditional for the arts. Representation of the past also depends on the audience of this message. New players have emerged within the field of contemporary information channels: the bloggers. The past in its mythologised and documentary modes of existence is transmitted to the generation that lacks personal Soviet experience. This transmission requires from the authors - i.e., the bloggers creating artistic texts - both to utilise the existing strategies and to develop the new ones.

\section{Methods}

To answer the proposed questions, the following research procedures have been used:

1. analysis of art texts and audience responses to elucidate the main strategies applied to working with Soviet past. The interpretation of 'nostalgia' concept utilises discourse analysis to reveal the dynamic character of its semantic nucleus. 
2. the next step in our research is to trace the differences between the audiences within the context of retro-orientation of contemporary Russian culture.

3. comparison between the three main strategies of working with the past: aesthetisation, mythologisation, and deconstruction/demythologisation.

\section{Discussion}

\subsection{Case 1}

The Thaw: TV series by Valery Todorovsky. TV series The Thaw focuses on the most indisputable achievement of 1960s: cinema and its creators. The plotline revolves around a film shooting, during which the eminent director Fyodor Krivitsky transfers shooting rights to the young filmmaker Yegor Myachin. The other subplots feature cameraman Khrustalev and the shooting crew, and a tragic death of a talented scriptwriter whose script Khustalev promised to make into a movie at all costs. In this series Todorovsky is engaged in simultaneous construction and deconstruction of the past. The director inhabits a critical discourse: he loves, he wonders, he hates. The latter feeling comes to him less naturally - rather, he is trying to divest the past of its romantic aura, showing it as a period where idealism could placidly co-exist with cynicism, moral rectitude with conformism, [3] conservatism with unexpected support of the youth (as happens in the episode where Fyodor Krivitsky, a holder of Stalin award played by Mikhail Yefremov, defends young Yegor Myachin while wearing a military overcoat borrowed from the stage props). The director offers his own strategy for understanding the circumstances and his characters. Meanwhile, his characters completely disregard the ideals of socialist realist life where the communal needs were supposed to supersede the personal ones. The two main characters, Viktor Khrustalev (actor E.Tsyganov) and Yegor Myachin (actor A.Yatsenko), demonstrate an inversion of the private and the public, the moral principles and the laissez-faire approach. Thus, Yegor Myachin, an inveterate truth-seeker and non-conformist, forgets that he was supposed to take Khrustalev's place in the reception office of the Mosfilm studio director - forgets, because he has fallen in love at first sight. At the same time, cynical and conformist Khrustalev remembers that he is supposed to meet his wife but cannot leave the reception office, because he puts his obligations to his friend before his private life. And Khrustalev's father (actor A. Smirnov), an official belonging to the Soviet academic nomenklatura, working throughout his life to advance his country's war preparedness, used to abuse his position for personal goals - humane and understandable when 
applied to his family but reprehensible in terms of public morals under the conditions of 'people's war, sacred war'.

The series features a lot of external markers of the era: in art, and especially in cinema, they are the material that conjures up a Zeitgeist - a radiogramophone, a cezve, people waiting in line to get to the Sovremennik movie theatre while talking about "the artists' new way of life", a tree branch shaped as a sputnik. Among other markers of the era are: a slide strip viewed by the elder Khrustalev's younger son, a song Let's never have a fight, Voice of America radio broadcasting about Rudolf Nureyev, as well as the incurable rudeness and callousness of repressive institutions, both judiciary and medical ones. On top of these markers of the times, the series includes important metaphysical themes that provide the storyline with its energy. One of them is a presence of mystery. Almost all characters have their own mysteries, and they include not just the innocent mysteries of childhood (a secret place of Khrustalev's daughter, a stolen geometry box of Maryana Pichugina, a nude sketch made by Khrustalev in his first grade). There are also mysteries of a different order, which haunt our heroes and, if disclosed, can lead to horrifying consequences: because they live during the 'thaw', not the spring, Stalin died only eight years ago and, furthermore, he died 'not for everyone', according to the battle veteran and now studio director (V.Gostyukhin). There are unsolved mysteries, such as a suicide of non-conformist screenwriter Kostya Parshin - and then there are mysteries that hold the prospects of criminal persecution and public ostracism. These mysteries shape an image of the age, when homosexuality is punishable by imprisonment and the disclosed story of Khrustalev's 'reservation' - by public contempt. These two episodes (the arrest of costume designer Sancha (Evgeny Volotsky) and the newspaper article arranged by investigator Tsanin to destroy Khrustalev) reveal another important marker of the era: its propensity to the expressions of public condemnation. The people who, seemingly, should be able to doubt and ask questions, behave exactly as the 'consolidated' masses. Only when reaching the finale, we learn a solution to another mystery - the mystery of the Pichugin family, which we can only dimly guess at the beginning (why Sancha and Maryana leave with their grandmother). This mystery is also typical for the 1960s, when the truth about repressions was already known, but people still preferred to keep quiet about it.

Todorovsky's lyrical intonation combines with a critical one, which helps the director locate the sources of repressive streak not within the workings of repressive apparatus but within the people themselves. Since the director was making an 'industry film' about art, the repressive force here is represented not only by the Artistic Council ("Who was laughing?") but also by the audience that masks with incomprehension its 
own complexes and its perpetual suspicion that they are not shown enough respect. The investigator perpetuates this rhetoric of misunderstanding when, drunk, he rails at the film crew: "Who do you think you are?! It's the ordinary people who feed you! Who do you think you are?!"

Todorovsky's series lacks outright nostalgia for the Soviet past. Even the muchmentioned cleanliness (the thaw-era movies feature a lot of cleaning machines flushing city streets) as a sign of order and health is challenged by the Khrustalev's movie. The viewers do not see this imaginary movie, but there are several discussions showing that dust (as an antithesis to the 'sterile' and the 'correct') becomes an important semantic detail of Khrustalev's film rejected by his audience. Equally, the poems, another marker of 'poetic cinema' referencing famous readings at the Polytechnical Institute, appear not as a symbol of freedom expressed by strolling couples in love, but as a sign of violence (one of the most dramatic moments in the show occurs when, as part of an investigative experiment, Khrustalev is forced to read aloud Yevgeny Yevtushenko's poem dedicated to Bella Akhmadulina, Here is what's happening to me).

Todorovsky offers his own strategy for living without nostalgia. His critics accused him of omitting too much of 1960s sociocultural context: talks about politics, Yuri Gagarin's space flight etc. However, instead of the widely recognizable markers of 1960s, the director offers an episode where the totalitarian past/present comes to life even at a level of somatic memory - the gestures that reflect the victim's state of fear and subjugation and the executioner's confidence.

Todorovsky shows that it is possible to overcome nostalgia without engaging in direct critique of the Soviet past. The audience are told and shown a story about Soviet professionals who can be conformist, mean and cynical in their private lives, and yet prove themselves the true masters of their work. For the characters, creative process is a welcome disease, a front, a battle in which some, the most uncompromising ones, jump from the window, while others try to sublimate their guilt in artistic messages.

Not by chance the last name of the main character is Khrustalev (an obvious reference to Aleksei German's most antitotalitarian film, Khrustalev, My Car!), and it does not matter that he was 'copped out' of his military duty. It is he ("a scoundrel and an artist") who defends the thaw's main achievement - a right for individual expression - and he does it at his workplace (he is a professional!) by punching an insolent investigator who was insulting the film crew in a drunken rage. Paying no attention to whispers and shouts of “Vitya, don't!", Khrustalev knocks down the system's representative. This seems to be the only instance when Todorovsky casts aside his distancing view of the past and 
expresses himself directly and unequivocally, and the positions of the director and his character coincide.

\subsection{Case 2}

Kolyma Tales. A performance by Yeltsin Centre's theatre studio ' $\mathrm{V}$ tsentre'.

This performance is addressed to the younger audience. The comments left by the viewers show that they had not previously read Kolyma Tales, although they had heard something about the GULAG. Therefore, during each performance the actors become engaged in a dialogue with the viewers devoid of historical knowledge, who possess mostly a proximate mythological image of the past. The viewers' sensory experiences are not only individual but also collective, received while ascending to the Yeltsin Centre's 4th floor, since the theatre studio ' $V$ tsentre' is located in a modern, consumer-oriented building overflowing with multimedia rooms, co-workings, fashionable boutiques, expensive cafes and restaurants. The producers' goal is not to succumb to the spirit of denunciation, especially because Shalamov himself hated pathos and melodrama. The performance's authors and participants try to create an authentic situation, to understand and visualise, bring to life events and situations unimaginable to those living today. The only iconic image used during the play is an onscreen projection of larch and the skeleton of larch printed on ascetic cardboard programme. The larch is a marker of place, as well as of Shalamov's story titled Resurrection of the Larch, where the author tells the readers that to survive humans need to believe in miracle: "We are superstitious. We demand a miracle. We make up symbols and live through these symbols". [4] "Living nature's dead branch" is a symbol that is easy to understand regardless of the viewers' cultural background.

Kolyma Tales performance is a mixture of texts taken from the writer's stories. The texts are not assembled as a sequential storyline but rather as a scattering of scenes tied together by the two common themes of hunger and fear. The playwright Yaroslava Pulinovich chose Kolyma Tales reflecting on the basic human needs: to breath and to eat. This chamber performance takes place in an empty rectangular space of a room where the viewers sit facing each other. The centre is occupied by a large barrel drum, which, depending on the plot, may become a cast-iron stove, a prison camp bell or a gong. But from the very beginning, the viewers are immersed in a total space of cold created by the sound of wire scraping the metal - a palimpsest of artificial sounds recreating the inhumane reality of prison camps. 
The play uses neither reconstruction of historical details nor actors' immersion into the characters of camp inmates or their superiors. Director Aleksei Zbegin and playwright Yaroslava Pulinovich ground their vision in the fact that, as critic Oksana Yefremenko puts it, "it is difficult today to relate Shalamov's stories to the concrete individual lives". [5]

From the hunger and the cold, which are impossible to recreate within the warm fashionable space of Yeltsin Centre, arises a prison camp tale about a dying poet. The camp legend about Osip Mandelstam's death taken from the Cherry-Brandy story is told dispassionately. It is more than a biographical story and a personal myth. From mythologically distanced intonations the performance moves towards the tangible and recognizable ones. These are the stories about food - or, rather, about the constant dreams about food, the pervading lack of food. Inhabiting these stories, the actors utilize ordinary everyday intonations and gestures rejecting artistic conventions. The story of four prison camp inhabitants almost dying from hunger ('goners' in labour camp jargon), the heroes of the tale Dry Rations who are sent to work in the woods and find shelter in a miners' cabin, is based on recognizable sensory experience. For the first time, the viewers can participate in these small joys of food preparation. The actors' intonations are completely convincing and, what's most important, they feel real. These scenes are used by the play's authors to achieve Shalamov's main goal, "to evoke a feeling - the very same feeling that people experienced under the inhuman camp conditions". [4]

Kolyma Tales' logic and truth lie in the absence of happy ending. Any hope is pure luck: not by chance, after a vivid and colourful description of a short and rare miracle of having food every day, the author of the performance proceeds to recite a long list of the dead. The barrel drum becomes a metronome whose every blow represents an individual fate:

They all died... Nikolay Kazimirovich Barbe, one of the creators of Russian Komsomol..., los'ka Ryutin died. He agreed to work in pair with me when the tough workers did not want to be saddled with me... Economist Semyon Alexeevich Sheynin died, a very kind person... Ivan Yakovlevich Fedyakhin. We were on the same train, on the same steamer. Found ourselves in the same mine, in the same brigade. He was a philosopher, a peasant from Volokolamsk, an organizer of the first kolkhoz in Russia. This is what he was imprisoned for, because he organized the first kolkhoz... Derfel died. He was a French communist... [4] 
The performance concludes with the recording of Shalamov himself, his image projected onscreen: the writer asks to remember his tales, or the past may yet repeat itself.

\subsection{Case 3. Yury Dud. Kolyma -- Birthplace of Russia's Fear}

The two-hour long film titled Kolyma - Birthplace of Russia's Fear was broadcasted on Yury Dud's YouTube channel vDud on 23 April 2019. This video uses lives of famous people (airplane designer Sergei Korolev, writer Varlam Shalamov, actor Georgy Zhzhenov, family of actor Yefim Shifrin) to tell about the Stalin's purges and their main institutional incarnation - the GULAG system. At the same time, Dud makes a point of saying that his work is not about the past but about the present: he believes that the fear generated by the Soviet experience survives in modern Russians and influences the country's future.

Yuri Dud's movie about Kolyma surpassed all ratings of the TV shows. Millions of views on his YouTube channel made the blogger the main public educator of 2019. At the same time, Dud attracted vitriolic criticism from conservatives and right-wing patriots, such as Zakhar Prilepin. The film is significant within the context of Stalin's growing popularity, especially among the younger generation. This is why Kolyma... is not only a meditation on history but a concise expression of the filmmaker's position, which amounts to a project of deconstructing the myth about the Great Leader.

Dud's audience is almost the same that the audience of the Kolyma Tales - that is, young people who had never lived in the USSR and never read the 1990s literary journals that published the materials on the Great Terror. Moreover, the blogging audience usually shows no interest in politics. The author himself was born in 1986, in the waning years of the USSR. For this reason, his life can also be described as life without Soviet experience. At the same time, Dud acknowledges the influence his parents' attitudes have had on his life:

I don't know about you, but l've been hearing from my parents all my life: be careful, keep your head down, don't stick out, sticking out is very dangerous; and, in general, we are ordinary people, we can change nothing... I've always asked myself - where did the older generation get this fear, this desire to cover everything in grey? Why are they afraid that even a tiny bit of boldness is bound to be punished? My hypothesis is: this fear was born back in the last century and was handed down to us through the generations. One of the places where this fear was created is Kolyma. [6] 
Yury Dud occupies several roles: he is an explorer, a traveller, an interviewer, and a travel buddy. The roles of a judge or a persecutor are completely absent. He becomes a guileless and naive commenter surprised by the fact that Novosibirsk now has a monument to Stalin; he sincerely strives to hear the diverse voices, from the daughter of Sergei Korolev to an ex-convict.

Dud works within a popular genre of 'road movie' travelling the 2,000-kilometer length of Kolyma, from Magadan to Yakutsk. He confronts his potential viewers with simple everyday observations about physiological sensations and ordinary situations: for example, what he and his travel partner wear (the answer is: clothes with modern thermal insulation). These simple questions help us to become immersed in a permafrost landscape, in which Soviet citizens lived and died.

A road movie always presupposes aesthetic contemplation. Yury Dud combines, in a counterpoint arrangement, tales about inhuman sufferings with sublime incommensurability of nature, the pragmatics of economic considerations (gold was badly needed for national development) with the ethics of labour camp life. The dispassionate tone of presentation provides a suitable vehicle for the theme of the banality of evil, one of the main characteristics of totalitarian past. On the one hand, this life is unbearable, on the other, people cannot imagine themselves living in a different place. Such dichotomies help the filmmaker to envision contemporary Russia through a nostalgia-free lens.

\section{Conclusions}

1. The article has explored different ways of working with Soviet past: nostalgia and the overcoming of nostalgia.

2. It describes the conditions fostering emergence and spread of nostalgic feelings.

3. It has analysed several stages in the work with the past: aesthetisation, commercialisation, mythologization, deconstruction.

4. By analysing Valery Todorovsky's TV-series The Thaw, Zabegin's and Pulinovich's Kolyma Tales performance by Yeltsin Centre's ' $V$ tsentre' theatre studio and Yury Dud's YouTube film Kolyma - Birthplace of Russia's Fear it was possible to demonstrate how artistic strategies depend on the art form and genre chosen by the authors, as well as on the differences between their audiences. 


\section{References}

[1] Chase, M. and Shaw, C. (1989). The Dimensions of Nostalgia. In The Imagined Past: History and Nostalgia. Manchester: Manchester University Press, 1-18. Editors: Chase, $M$.

[2] Kustaryov, A. (2007). Zolotye 1970ye - nostalgia i reabilitatsiya. Neprikosnovennyi zapas, vol. 2, issue 52, p. 7.

[3] Kruglova, T. (2014). The Conformism of the 60's Generation at an Aesthetic Distance. Internet-Journal KinoKultura, issue 44. Retrieved from http://www.kinokultura.com/ 2014/issue44.shtml.

[4] Shalamov, V. Voskresheniye Listvennitsy. 1966. Retrieved October 1, 2019 from https: //shalamov.ru/library/5/31.html.

[5] Peterburgskiy teatralnyi zhurnal Blog. (2017, June). Retrieved October 1, 2019 from http://ptj.spb.ru/blog/shalamov-mezhdu-mifom-idokumentom/.

[6] Dud, Y. Retrieved October 3, 2019 from https://yurij-dud.ru/interview/kolyma-rodinanashego-straha-vdud/. October, 2019. 